\title{
Psychological Research Collaboration and Visibility in Iberoamerica
}

\section{A Visibilidade e Cooperação da Pesquisa em Psicología na Ibero-América}

\author{
Wilson López-López ${ }^{\mathrm{a}, *}$, Félix de Moya Anegón ${ }^{\mathrm{b}}$, César Acevedo-Triana $^{\mathrm{c}}$, Agnaldo Garcia ${ }^{\mathrm{d}}$, \& \\ Luis Manuel Silva ${ }^{\mathrm{a}}$ \\ ${ }^{a}$ Pontificia Universidad Javeriana, Bogotá, Colombia, ${ }^{b}$ SCImago Research Group, Madrid, Spain, ${ }^{c}$ Pontificia \\ Universidad Javeriana, Bogotá, Colombia \& ${ }^{d}$ Universidade Federal do Espirito Santo, Vitória, ES, Brazil
}

\begin{abstract}
The phenomenon of collaboration is an increasing trend in many fields of science, including that of psychology. In Iberoamerican psychology, collaboration occurs on a local and international level. The aim of the study was to evaluate the levels of collaboration in Iberoamerica, using as a baseline the level of worldwide collaboration in psychology in 2012. We collected data from the Scopus database and analyzed it by cluster distribution. Analysis of the sample found within-country collaboration prominent among Iberoamerican psychologists. Findings indicated that in Iberoamerica there is significantly less global collaboration than in other regions, although Iberoamerican scientists are receptive to the idea and acknowledge its potential.
\end{abstract}

Keywords: Scientific production, psychology, collaboration, Iberoamerica

\begin{abstract}
Resumo
O fenômeno da colaboração é uma tendência em crescimento em muitos campos da ciência, incluindo a psicologia. Na psicologia ibero-americana a colaboração vem ocorrendo em nível regional e internacional. O objetivo deste estudo foi avaliar níveis de colaboração em Ibero-América, usando como linha de base o nível de colaboração mundial em psicologia nos anos de 2012. Os dados foram coletados da base Scopus e analisado pela distribuição de dados segundo seu grau de agrupamento (cluster). A análise mostrou que a colaboração entre ibero-americanos é maior dentro dos respectivos países e menor em nível global. Mesmo assim, destaque-se que cientistas ibero-americanos são receptivos a ideia de internacionalização e reconheçam seu potencial.

Palavras-chave: produção científica, psicologia, colaboração, Ibero-América
\end{abstract}

Science is a social practice. In many cases, it depends on interaction and partnership, and collaborative relationships (Bozeman \& Corley, 2004). Once these collaborative relationships are established, they are sustained through scientific output-published articles produced by the collaborators - and the attention that that output draws. Collaboration, however, occurs on different levels: locally, nationally or internationally (ChinchillaRodríguez, Vargas-Quesada, Hassan-Montero, GonzálezMolina, \& Moya-Anegón, 2009; Guerrero Bote, OlmedaGómez, \& de Moya-Anegón, 2013). Studies indicate that internationalization is a factor related to the mechanism of collaboration (Chinchilla-Rodríguez et al., 2009; Guerrero Bote et al., 2013).

Some authors attribute the recent increase in scientific collaboration to the accessibility of internet and technology,

Correspondence concerning this article should be addressed to Wilson López-López, Facultad de Psicología, Pontificia Universidad Javeriana, Edificio 95 - Manuel Briceño S.J. Carrera 5 No. 39-00 Bogotá, D.C. Colombia. E-mail: lopezw@javeriana.edu.co. the internationalization of training programs, and students exchange and training of doctoral and postdoctoral researchers. They additionally cite the increase of economic incentive for collaborative work (GarcíaMartínez, Guerrero-Bote, \& Moya-Anegón, 2012; Kliegl \& Bates, 2010; Romero-Torres, Acosta-Moreno, \& TejadaGómez, 2013). It is thus clear that increasing opportunities for collaboration may increase incentives for collaboration, and thus increase scientific output (Easterbrook, 1993; Johnson, 2009; Porac et al., 2004).

One way to measure international collaboration is through the analysis of output from researchers, joint projects, academic events, and research training (Chinchilla-Rodríguez et al., 2009; Garcia et al., 2014). Following Chinchilla-Rodríguez et al. (2009), we understand that collaboration is the reflection of an individual and institutional process that promotes generation of output, first and foremost which are scientific articles. Publications are not the only way to measure the collaboration process, given that they can generate material 
difficult to evaluate in terms of long-term scientific merit; but they do serve as a means to quantify collaboration. For the purpose of this paper, collaboration will be defined as output derived from co-authorship between researchers at different institutions (Chinchilla-Rodríguez et al., 2009; Garcia et al., 2014; Katz \& Martin, 1997).

This collaboration generates levels of analysis beyond the number of published articles. We must consider variables such as authorship criteria, design, implementation and development, considering the contribution of each author to the final output (Allen, Brand, Scott, Altman, \& Hlava, 2014; Shen \& Barabasi, 2014). On the other hand, contexts such as participating institutions, area of expertise, and countries of the principal authors influence the impact of products as well (Guerrero Bote et al., 2013). In general, international cooperation is associated with higher visibility and higher impact. Various studies have tried to characterize the collaboration parameters by regions (Guerrero Bote et al., 2013). Thus, one collaboration analysis between China and other countries demonstrated that while the growth of the number of publications increases among the countries of high economic level, the impact of these publications does not increase in the same way (He, 2009). More comprehensive reports suggest there is a system that favors countries with wider science resources (Leydesdorff \& Wagner, 2008). On the other hand, contexts such as participating institutions, area of expertise, and countries of the principal authors also influence the impact of products (Arencibia Jorge \& de Moya Anegón, 2008; Cervi, Galante, \& Oliveira, 2013; García-Martínez, Guerrero-Bote, HassanMontero, \& Moya-Anegón, 2009; Lovón Canchumani, Leta, \& Figueiredo, 2013). In the case of psychology, there have been attempts to use these kinds of measures to improve program quality and the prestige of researchers (Alzate-Medina, 2008; García-Cepero, 2010; López, Silva, García-Cepero, Bustamante, \& López, 2011).

The incidence of collaboration is closely associated with subject field. In the humanities, for example, the sense of authorship is strong and collaboration among authors is low (Bordons, Gomez, Fernandez, Zulueta, \& Mendez, 1996; Garcia et al., 2014; Salazar-Acosta, Lucio-Arias, López-López, \& Aguado-López, 2013). This feature is probably related to the way products relate to the contexts in which they are produced. In the field of psychology, recent studies show that high productivity is concentrated in some countries; therefore the way these researchers collaborate could be used as a model for other countries to increase research (García-Martínez et al., 2012; Guerrero Bote et al., 2013). Geographical proximity and language could be seen as factors that could enhance communication. Studies indicate that when English is used as a lingua franca of science, visibility can increase for productions from countries where English is not the native language, even for works related to local issues. (Morales, Jaraba-Barrios, Guerrero-Castro, \& López-López, 2012). The cooperation phenomenon is so complex that even publications favor those products that do not present a sectorial emphasis in the focus of the magazine, but on the contrary, that allows to maintain publications as a real channel dissemination of relevant knowledge and international use (Vera-Villarroel, López-López, Lillo, \& Silva, 2011).

\section{Psychology in Latin America}

In Latin America the dynamic of production and consumption of knowledge are different from the dynamic at the international level (Alonso \& Sánchez, 2005; Delgado, 2011). Although psychology in Latin America has experienced a sustained growth in production (López et al., 2011), the visibility of the knowledge generated nowadays has had a wide participation due to the inclusion of Latin American psychology journals in international indexes (Navarrete-Cortés, Fernández-López, LópezBaena, Quevedo-Blasco, \& Buela-Casal, 2010; QuevedoBlasco \& López-López, 2011). The internationalization of this knowledge has shown that scientific journals have turned out to be a privileged channel for production visibility (Rivera-Garzón, 2008; Zych \& Buela-Casal, 2010). In this regard, the measurement of 2013 indicates that Iberoamerica has had several publications in Scopus, from which 34 are from Latin America and 22 are from Spain. In terms of production, countries like Chile, Colombia, Argentina, Brazil and Spain account for over a thousand documents from 1996 to 2013, and Spain and Brazil are among the countries with the highest production. In terms of psychology production worldwide, Spain ranks $9^{\text {th }}$ and Brazil $15^{\text {th }}$. These preliminary results show a particular and important tendency in the contribution of psychological documents worldwide. Regarding the trend in cooperation between researchers, approximately $25 \%$ of the works are credited to single authors. This trend did not diminish but remained stable, or even increased, suggesting a particular profile of some researchers (Scimago Group, 2014). Considering the above, the aim of this work is to describe the trend of global cooperation, with an emphasis on the cooperation in Latin America and Iberoamerica.

\section{Method}

Using the Scopus database, we examined psychology production with a focus on authors and institutional affiliation between at least two different countries to define the collaboration (Garcia et al., 2014). We developed two bibliometric maps according to the methodology described by Hassan-Montero et al. (2014). In short terms, we used as a unit of analysis the international scientific journals in which we evaluated the data on three previously standardized measures: citation, co-citation and bibliographic coupling.

We used the data from the Scopus database (20032013) with the general qualification of "Psychology" in all the areas. The nodes are represented by circles in 
which the size of the area indicates the weight within the chosen indicator and the color represents the node to which it belongs (Hassan-Montero, Guerrero-Bote, \& Moya-Anegón, 2014). For the descriptive results, data from international and Latin American bases in Scimago were consulted (http://www.scimagojr.com/).

\section{Results}

\section{Descriptives}

Within the countries of the region (Iberoamerica) that contribute the largest amount to the worldwide psychological production, there are six countries: Spain ( $9^{\text {th }}$ place, 14,927 documents); Brazil $\left(15^{\text {th }}\right.$ place, 7,379 documents); Mexico (25 th place, 3,071 documents); Portugal ( $31^{\text {st }}$ place, 2,469 documents); Colombia ( $40^{\text {th }}$ place, 1,109 documents) and Chile (41 ${ }^{\text {st }}$ place, 1,095 documents) (Table 1). As for the production in Latin America, we found in first place Brazil (7,379 documents), followed by Mexico (3,071 documents) and Argentina (1,276 documents), then Colombia (1,109 documents) and Chile (1,095 documents).

We also found that the distance between the first and second place (Brazil and Mexico respectively) is more than double the production of the second place $(48.1 \%$ of Brazil and $20 \%$ of Mexico) and the distance of the first five places is far from the rest of the countries (Table 2). When analyzing the relationship between the documents and the quotations, we found a high correlation $(r=0.989, p<$ $0.0001 ; r^{2}=97 \%$ ), indicating that the growth in production is associated with growth in quotation. This relationship is not the case in Puerto Rico, however, where production is low (336 documents) in comparison with the number of citations reported (7,281 citations). The same asymmetrical relationship also appears in Panama with 24 documents and more than 1,500 citations, which indicates that there are more than 147 citations per document produced. If we consider the mean of citations among the 20 countries, without considering Panama, we find around 13.15 citations per document $(\mathrm{DE}=6.78)$; therefore it is difficult to understand the behavior of 147 citations per document in the case of Panama $(0.2 \%$ in the region population) which places it in first place if we organize the data by this item.

Another relevant relationship to analyze is the one between co-authorship and citations, in which we found that the greater the number of the authors per work, the greater the number of citations of the study, as a function of the increase in possible sources of citations. In this analysis, we examined this parameter by country (Table 3 ). In the case of Puerto Rico and Panama, we found that the high amount of citations was due to an article that generated around 15,000 citations. The article was in the area of health, in which more than 15 countries collaborated. Since the production in these countries is high, it does not allow us to reflect about the phenomenon of inflation that we can see in countries with low production. Thus, in cases in which productive profiles are low, the measurement of citation counts per document is not a good indicator of this relationship. A good example can be seen in Table 4, where it is evident that as the number of authors in an article increases, the number of citations increase, reaching a maximum of eight authors per article. This feature suggests a positive relationship between the number of authors per article and the number of citations that article receives.

\section{Cooperation Networks}

To analyze the results of collaboration, we performed first a graphic grouping of global cooperation, following the method of Hassan-Montero et al. (2014). In Figure 1, we can observe that the extent of participation of countries is given by the size of the circles, i.e., the greater the area, the greater the participation; and the proximity of the countries in the graph indicates the strength of this collaboration. Additionally, the intersection of the circles shows the cooperation between the countries, according to the country of the authors' affiliation. Thus, the proximity between the countries and the intersection expresses the strength of cooperation.

As can be observed in Figure 1, there is a group of countries that have higher levels of cooperation. To facilitate the understanding, information was grouped by variables into several clusters. Cluster 1 (cluster EEUU) is characterized by collaborations around United States and England, some close countries as Canada, Australia, Korea and Israel are represented in a spatial proximity and this would be given by the intensity in scientific and academic relationships generated by these countries and the EEUU. In second place, another cluster would consist of Iberoamerican countries, such as Spain, Brazil, Portugal and Colombia, and close to this one is seen other Iberoamerican countries such as Mexico, Philippines, Chile, Argentina, Venezuela, Peru, and Costa Rica. In this second cluster, despite having a common language, there is a geographical distance between Portugal and Spain and the other European countries with high productivity such as Germany, France and the triplet of Switzerland, Finland and Norway. In Iberoamerica, there is a particular interaction between Argentina, Chile, Venezuela and Peru. It does not make any difference that the language similarity largely corresponds to a geographical proximity. In this analysis, in addition to the intersection, the proximity defines inclusion in the cluster. In the European cluster, there are several groups indicating differences in the preference for cooperation, thus the Central European countries (Germany, Holland, Belgium, Switzerland, Luxembourg, Bulgaria and Austria) would form a type of individual interaction. In a second place, the Western European countries would form another particular interaction (Hungary, Romania, Poland, Czech Republic, Lithuania, Estonia, Malta, Slovenia and Bosnia). In the case of a smaller group of Northern Europe, there are the countries of Finland, Sweden and Norway. With respect to Asia, the interaction between China, Japan, Taiwan, Iran, New Zealand, India and Malaysia is clear. 
López-López, W., Anegón, F. M., Acevedo-Triana, C., \& Garcia, A. (2015). Psychological Research Collaboration and Visibility in Iberoamerica.

Table 1

Ranking of Countries in Terms of Production in Psychology for the Period of 1996-2013

\begin{tabular}{|c|c|c|c|c|c|c|c|}
\hline & Country & Documents & $\begin{array}{c}\text { Citable } \\
\text { documents }\end{array}$ & Citations & Self-Citations & $\begin{array}{c}\text { Citations per } \\
\text { Document }\end{array}$ & $H$ index \\
\hline 1 & United States & 283,925 & 271,992 & $5,533,083$ & $2,279,002$ & 22.18 & 456 \\
\hline 2 & United Kingdom & 68,288 & 63,963 & $1,182,659$ & 227,988 & 20.97 & 262 \\
\hline 3 & Canada & 39,470 & 38,027 & 722,252 & 102,778 & 22.02 & 221 \\
\hline 4 & Germany & 37,062 & 35,426 & 499,069 & 112,049 & 16.73 & 191 \\
\hline 5 & Australia & 26,378 & 25,328 & 384,081 & 52,358 & 18.76 & 163 \\
\hline 6 & France & 26,041 & 25,103 & 191,672 & 32,003 & 9.88 & 135 \\
\hline 7 & Netherlands & 23,182 & 22,377 & 441,378 & 68,504 & 24.98 & 185 \\
\hline 8 & Italy & 15,250 & 14,456 & 176,042 & 26,393 & 15.93 & 128 \\
\hline 9 & Spain & 14,927 & 14,621 & 129,072 & 34,207 & 12.27 & 103 \\
\hline 10 & Japan & 11,141 & 10,906 & 93,796 & 14,675 & 9.56 & 92 \\
\hline 11 & Israel & 9,129 & 8,869 & 138,977 & 18,149 & 18.27 & 124 \\
\hline 12 & Belgium & 8,513 & 8,201 & 117,861 & 16,070 & 18.98 & 111 \\
\hline 13 & Switzerland & 8,009 & 7,691 & 96,517 & 9,949 & 16.19 & 104 \\
\hline 14 & Sweden & 7,624 & 7,394 & 121,811 & 15,150 & 19.07 & 115 \\
\hline 15 & Brazil & 7,379 & 7,197 & 39,397 & 7,551 & 14.67 & 71 \\
\hline 16 & New Zealand & 5,449 & 5,237 & 86,797 & 7,229 & 19.82 & 107 \\
\hline 17 & China & 5,249 & 5,095 & 39,380 & 6,326 & 16.28 & 69 \\
\hline 18 & Norway & 4,946 & 4,819 & 68,277 & 6,643 & 18.30 & 87 \\
\hline 19 & Turkey & 4,636 & 4,562 & 27,189 & 3,959 & 13.66 & 64 \\
\hline 20 & Finland & 4,558 & 4,418 & 74,045 & 8,294 & 19.83 & 93 \\
\hline 21 & Hong Kong & 4,250 & 4,148 & 60,132 & 7,430 & 17.38 & 90 \\
\hline 22 & Taiwan & 4,146 & 4,068 & 37,882 & 5,997 & 15.46 & 68 \\
\hline 23 & Austria & 3,781 & 3,589 & 41,051 & 3,718 & 14.58 & 80 \\
\hline 24 & South Africa & 3,626 & 3,517 & 26,516 & 4,892 & 9.13 & 62 \\
\hline 25 & Mexico & 3,071 & 3,001 & 16,454 & 2,186 & 6.58 & 48 \\
\hline 26 & Ireland & 2,987 & 2,759 & 28,142 & 2,865 & 11.64 & 66 \\
\hline 27 & South Korea & 2,977 & 2,896 & 30,490 & 2,621 & 17.04 & 67 \\
\hline 28 & Denmark & 2,793 & 2,671 & 36,645 & 4,162 & 18.04 & 72 \\
\hline 29 & Poland & 2,777 & 2,705 & 14,596 & 1,491 & 9.73 & 55 \\
\hline 30 & Greece & 2,495 & 2,437 & 22,544 & 1,969 & 11.70 & 57 \\
\hline 31 & Portugal & 2,469 & 2,403 & 18,325 & 2,293 & 16.80 & 54 \\
\hline 32 & India & 2,427 & 2,271 & 17,240 & 1,815 & 11.98 & 50 \\
\hline 33 & Iran & 2,003 & 1,971 & 6,844 & 1,210 & 15.87 & 34 \\
\hline 34 & Singapore & 1,868 & 1,828 & 19,208 & 1,503 & 14.73 & 58 \\
\hline 35 & Russian Federation & 1,737 & 1,713 & 10,734 & 1,124 & 10.65 & 43 \\
\hline 36 & Hungary & 1,602 & 1,549 & 18,400 & 1,612 & 18.45 & 61 \\
\hline 37 & Argentina & 1,276 & 1,228 & 10,110 & 1,352 & 14.20 & 41 \\
\hline 38 & Romania & 1,228 & 1,208 & 3,724 & 401 & 11.87 & 27 \\
\hline 39 & Czech Republic & 1,143 & 1,126 & 6,776 & 1,232 & 7.15 & 38 \\
\hline 40 & Colombia & 1,109 & 1,077 & 6,929 & 549 & 11.01 & 38 \\
\hline 41 & Chile & 1,095 & 1,074 & 5,993 & 1,151 & 9.92 & 33 \\
\hline 42 & Malaysia & 1,085 & 1,076 & 3,772 & 690 & 12.61 & 26 \\
\hline 43 & Croatia & 837 & 828 & 5,180 & 433 & 12.89 & 30 \\
\hline 44 & Slovakia & 674 & 670 & 2,730 & 624 & 4.33 & 22 \\
\hline 45 & Cyprus & 503 & 493 & 3,157 & 378 & 11.45 & 27 \\
\hline 46 & Slovenia & 471 & 462 & 3,875 & 312 & 12.29 & 31 \\
\hline 47 & Thailand & 450 & 432 & 4,977 & 188 & 24.50 & 27 \\
\hline 48 & Estonia & 439 & 426 & 5,142 & 643 & 15.76 & 35 \\
\hline 49 & Nigeria & 399 & 387 & 2,614 & 168 & 8.78 & 25 \\
\hline 50 & Iceland & 396 & 383 & 4,996 & 458 & 17.15 & 36 \\
\hline
\end{tabular}

Data collected from Scimago (http://www,scimagojr,com/). 


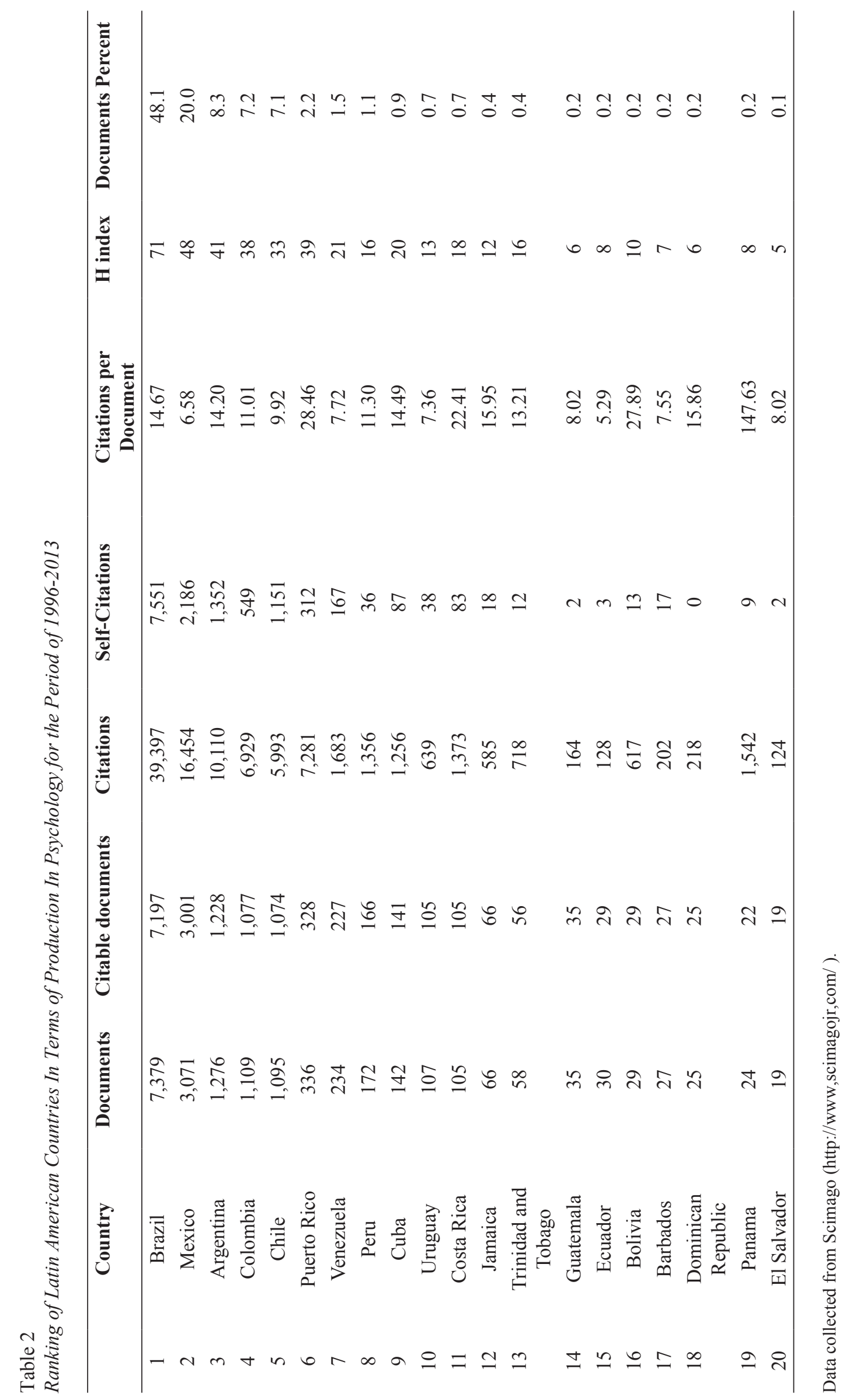


López-López, W., Anegón, F. M., Acevedo-Triana, C., \& Garcia, A. (2015). Psychological Research Collaboration and Visibility in Iberoamerica.

Table 3

Worldwide Psychology Production Ranked by Country 1996-2013

\begin{tabular}{|c|c|c|c|c|c|c|c|c|}
\hline & Country & Documents & $\begin{array}{c}\text { Citable } \\
\text { documents }\end{array}$ & Citations & Self-Citations & $\begin{array}{c}\text { Citations per } \\
\text { Document }\end{array}$ & $\begin{array}{c}\text { H } \\
\text { index }\end{array}$ & Dif \\
\hline 1 & Netherlands & 23,182 & 22,377 & 441,378 & 68,504 & 24.98 & 185 & 15.5204836 \\
\hline 2 & United States & 283,925 & 271,992 & $5,533,083$ & $2,279,002$ & 22.18 & 456 & 41.1886465 \\
\hline 3 & Canada & 39,470 & 38,027 & 722,252 & 102,778 & 22.02 & 221 & 14.2302133 \\
\hline 4 & United Kingdom & 68,288 & 63,963 & $1,182,659$ & 227,988 & 20.97 & 262 & 19.2775771 \\
\hline 5 & Finland & 4,558 & 4,418 & 74,045 & 8,294 & 19.83 & 93 & 11.2012965 \\
\hline 6 & New Zealand & 5,449 & 5,237 & 86,797 & 7,229 & 19.82 & 107 & 8.32862887 \\
\hline 7 & Sweden & 7,624 & 7,394 & 121,811 & 15,150 & 19.07 & 115 & 12.4373004 \\
\hline 8 & Belgium & 8,513 & 8,201 & 117,861 & 16,070 & 18.98 & 111 & 13.6347053 \\
\hline 9 & Australia & 26,378 & 25,328 & 384,081 & 52,358 & 18.76 & 163 & 13.6320203 \\
\hline 10 & Hungary & 1,602 & 1,549 & 18,400 & 1,612 & 18.45 & 61 & 8.76086957 \\
\hline 11 & Norway & 4,946 & 4,819 & 68,277 & 6,643 & 18.30 & 87 & 9.72948431 \\
\hline 12 & Israel & 9,129 & 8,869 & 138,977 & 18,149 & 18.27 & 124 & 13.0589954 \\
\hline 13 & Denmark & 2,793 & 2,671 & 36,645 & 4,162 & 18.04 & 72 & 11.3576204 \\
\hline 14 & Hong Kong & 4,250 & 4,148 & 60,132 & 7,430 & 17.38 & 90 & 12.3561498 \\
\hline 15 & South Korea & 2,977 & 2,896 & 30,490 & 2,621 & 17.04 & 67 & 8.59626107 \\
\hline 16 & Portugal & 2,469 & 2,403 & 18,325 & 2,293 & 16.80 & 54 & 12.5129604 \\
\hline 17 & Germany & 37,062 & 35,426 & 499,069 & 112,049 & 16.73 & 191 & 22.4516049 \\
\hline 18 & China & 5,249 & 5,095 & 39,380 & 6,326 & 16.28 & 69 & 16.0639919 \\
\hline 19 & Switzerland & 8,009 & 7,691 & 96,517 & 9,949 & 16.19 & 104 & 10.3080286 \\
\hline 20 & Italy & 15,250 & 14,456 & 176,042 & 26,393 & 15.93 & 128 & 14.992445 \\
\hline 21 & Iran & 2,003 & 1,971 & 6,844 & 1,210 & 15.87 & 34 & 17.6797195 \\
\hline 22 & Taiwan & 4,146 & 4,068 & 37,882 & 5,997 & 15.46 & 68 & 15.8307376 \\
\hline 23 & Singapore & 1,868 & 1,828 & 19,208 & 1,503 & 14.73 & 58 & 7.82486464 \\
\hline 24 & Brazil & 7,379 & 7,197 & 39,397 & 7,551 & 14.67 & 71 & 19.166434 \\
\hline 25 & Austria & 3,781 & 3,589 & 41,051 & 3,718 & 14.58 & 80 & 9.05702663 \\
\hline 26 & Argentina & 1,276 & 1,228 & 10,110 & 1,352 & 14.20 & 41 & 13.3728981 \\
\hline 27 & Turkey & 4,636 & 4,562 & 27,189 & 3,959 & 13.66 & 64 & 14.5610357 \\
\hline 28 & Malaysia & 1,085 & 1,076 & 3,772 & 690 & 12.61 & 26 & 18.2926829 \\
\hline 29 & Spain & 14,927 & 14,621 & 129,072 & 34,207 & 12.27 & 103 & 26.5022623 \\
\hline 30 & India & 2,427 & 2,271 & 17,240 & 1,815 & 11.98 & 50 & 10.5278422 \\
\hline 31 & Romania & 1,228 & 1,208 & 3,724 & 401 & 11.87 & 27 & 10.7679914 \\
\hline 32 & Greece & 2,495 & 2,437 & 22,544 & 1,969 & 11.70 & 57 & 8.73403123 \\
\hline 33 & Ireland & 2,987 & 2,759 & 28,142 & 2,865 & 11.64 & 66 & 10.1805131 \\
\hline 34 & Colombia & 1,109 & 1,077 & 6,929 & 549 & 11.01 & 38 & 7.92322124 \\
\hline 35 & $\begin{array}{c}\text { Russian } \\
\text { Federation }\end{array}$ & 1,737 & 1,713 & 10,734 & 1,124 & 10.65 & 43 & 10.4713993 \\
\hline 36 & Chile & 1,095 & 1,074 & 5,993 & 1,151 & 9.92 & 33 & 19.20574 \\
\hline 37 & France & 26,041 & 25,103 & 191,672 & 32,003 & 9.88 & 135 & 16.6967528 \\
\hline
\end{tabular}

Note. Data collected from Scimago (http://www,scimagojr,com/); Iberoamerican countries are highlighted. 
Table 4

Brazilian Psychology Articles: 2012

\begin{tabular}{ccccc}
\hline Authors & Documents & \% documents & Cites & Cites per document \\
\hline 1 & 1,363 & 26.82 & 1,047 & 0.77 \\
2 & 1,635 & 32.17 & 2,680 & 1.64 \\
3 & 778 & 15.31 & 1,814 & 2.33 \\
4 & 479 & 9.43 & 1,735 & 3.62 \\
5 & 296 & 5.82 & 1,374 & 4.64 \\
6 & 190 & 3.74 & 1,510 & 7.95 \\
7 & 117 & 2.30 & 1,083 & 9.26 \\
8 & 76 & 1.50 & 1,068 & 14.05 \\
9 & 43 & 0.85 & 602 & 14.00 \\
10 & 30 & 0.59 & 296 & 9.87 \\
11 & 14 & 0.28 & 236 & 16.86 \\
12 & 9 & 0.18 & 44 & 4.89 \\
13 & 6 & 0.12 & 55 & 9.17 \\
$>13$ & 46 & 0.91 & 1,302 & 28.30 \\
\hline
\end{tabular}

Note. Data collected from Scimago (http://www,scimagojr,com/); Authors, number of authors per work; Documents, number of articles.

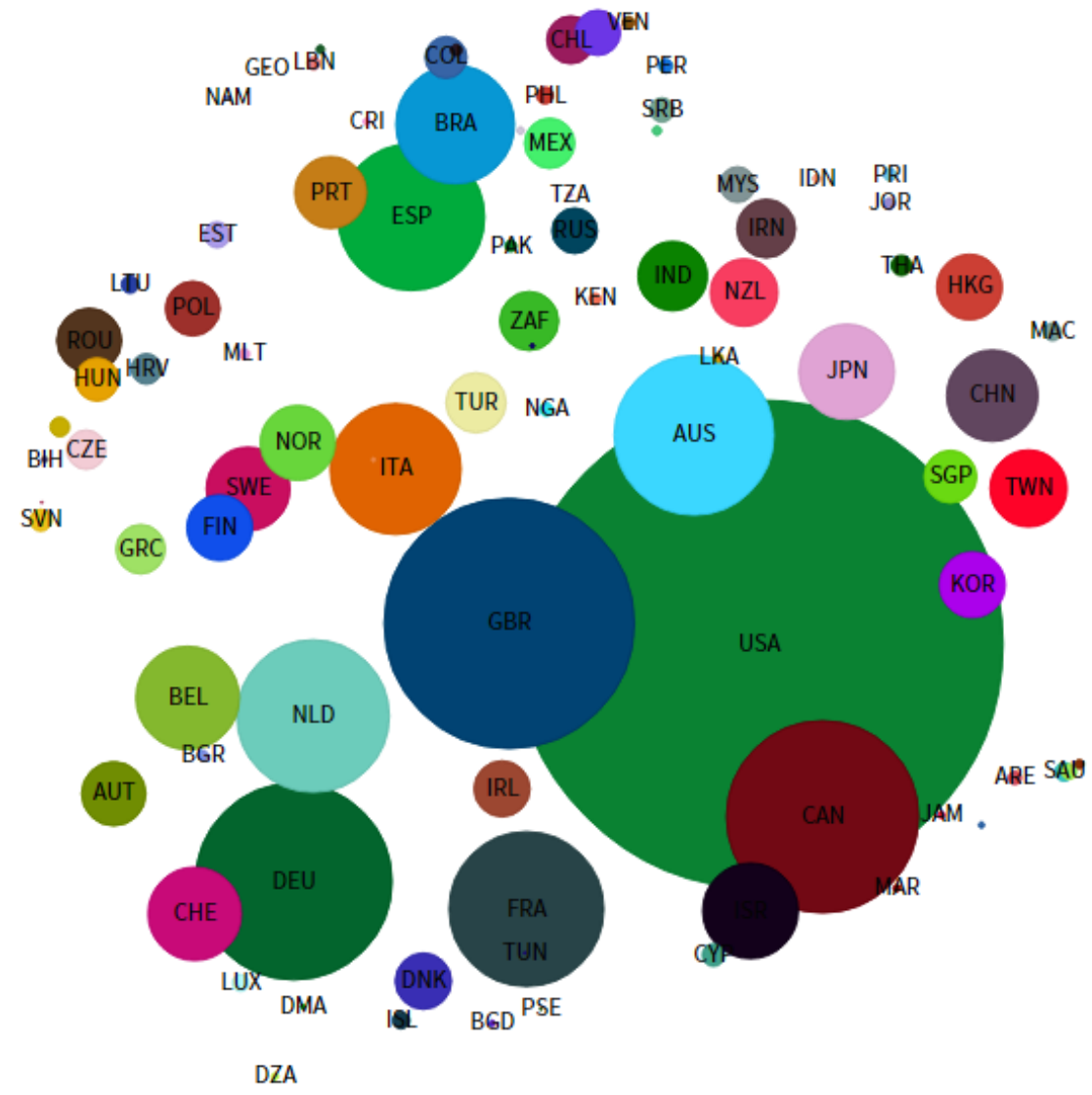

Figure 1. Collaboration network in psychology represented by countries in 2012.

Note. USA, United States; GBR, Great Britain; DEU, Germany; CAN, Canada; AUS, Australia; FRA, France; NLD, Holland; ESP, Spain; ITA, Italy; BRA, Brazil; BEL, Belgium; JPN, Japan; ISR, Israel; CHE, Switzerland; CHN, China; SWE, Sweden; TWN, Taiwan; NOR, Norway; PRT, Portugal; IND, India; NZL, New Zealand; FIN, Finland; KOR, Korea; HKG, Hong Kong; ROU, Romania; AUT, Austria; TUR, Turkey; ZAF, South Africa; IRN, Iran; DNK, Denmark; IRL, Ireland; POL, Poland; SGP, Singapore; MEX, Mexico; GRC, Greece; CHL, Chile; RUS, Russian Federation; HUN, Hungary; COL, Colombia; CZE, Czech Republic; MYS, Malaysia; HRV, Croatia; EST, Estonia; SRB, Serbia and Montenegro; CYP, Cyprus; SVN, Slovenia; THA, Thailand; SAU, Saudi Arabia; MAC, Macao; LTU, Lithuania; PHL, Philippines; LUX, Luxemburg; ISL, Island; PER, Peru; NGA, Nigeria; ARE, United Arab Emirates; LBN, Lebanon; PRI, Puerto Rico; VEN, Venezuela; JOR, Jordan; KEN, Kenya; PAK, Pakistan; MLT, Malta; BGR, Bulgaria; LKA, Sri Lanka; IDN, Indonesia; JAM, Jamaica; MAR, Morocco; CRI, Costa Rica; DZA, Algeria; BGD, Bangladesh; BIH, Bosnia Herzegovina; TZA, Tanzania; DMA, Dominica; TUN, Tunisia; GEO, Georgia; NAM, Namibia; PSE, Palestine. 


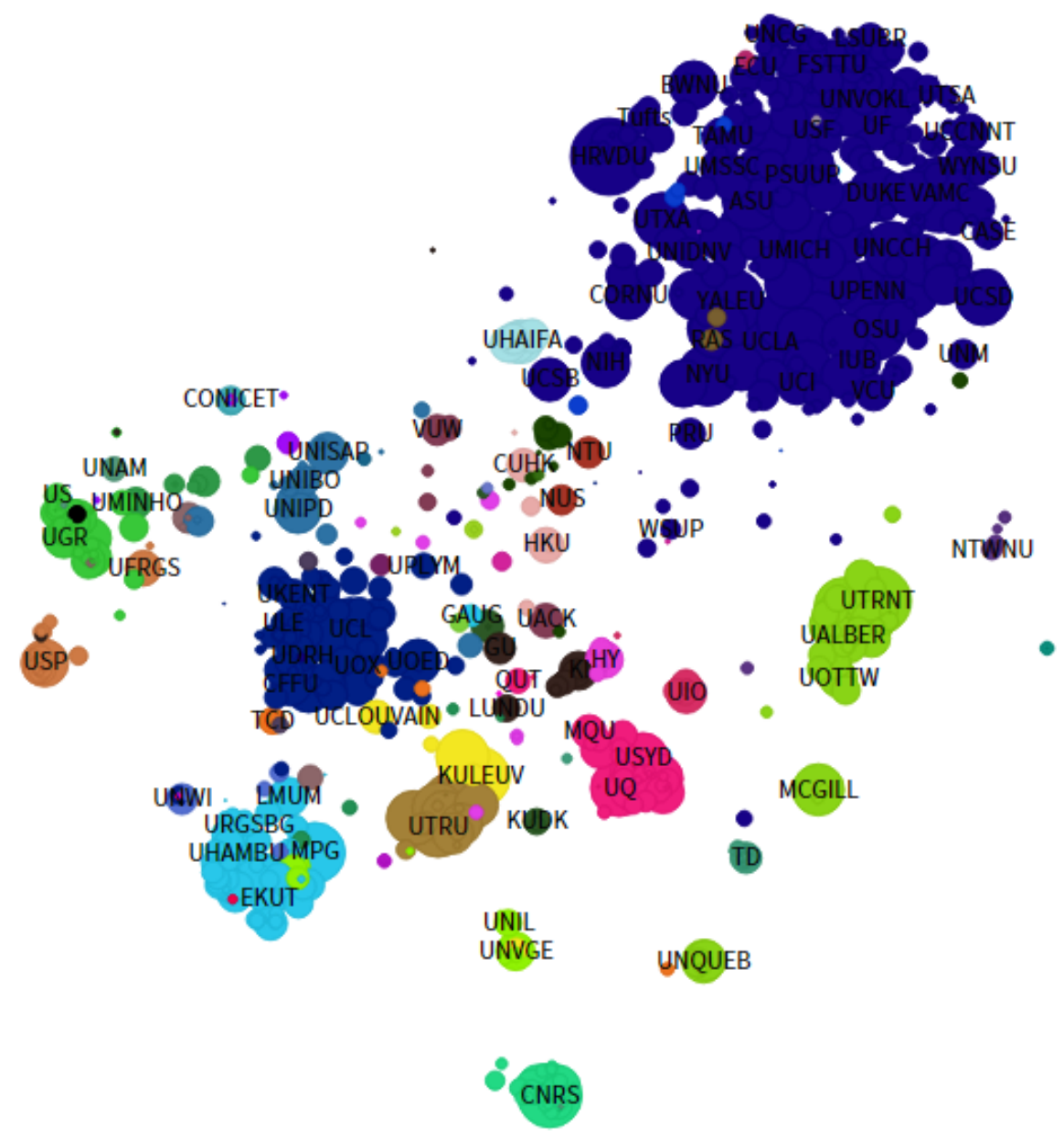

Figure 2. Collaboration network in psychology represented by institutions in 2012, colors correspond to countries.

Note. The colors represent the countries of origin of institutions.

In Figure 2 we confirmed that the distribution of institutional collaboration is found around the countries, which indicates a tendency for a local cooperation at a country-specific level. Unlike Figure 1, where it is shown that the proximity to United States could be due to an interest of the countries to cooperate by virtue of what such interaction represents for the collaborators; in the second figure, England assumes a more central role due to its size and geographical proximity with other countries. There is not a specific country that represents the center of the collaboration map, but instead, we find that the countries generate specific interactions by their sizes and production. In the case of Iberoamerican institutions, this is not represented in the map due to two main factors. First, the amount of collaborations is of less than 100 documents which is the cutoff point for the interaction to be represented in the graph, and second because specific collaborations are also not shown in the spatial representation.

\section{Discussion}

As for the global dynamic, a specificity and local behavior of each one of these is shown. It stands out the production and collaboration in psychology in North America, and highlights the high levels of participation within (inbred) versus an interest in some countries (Asia) to cooperate, for different reasons, with the United States of America, due to the prestige derived from this collaboration (Porac et al., 2004). Additionally and related to the cooperation interest with economic powers of North America, would be related explanations that favor scientific collaboration and associates it with economic power between countries. Collaboration among these countries could have increased over time in more traditional areas of science (biology, chemistry, engineering, clinical and neuroscience) but not necessarily have the same levels of interaction, despite regularizing variables such as language. He (2009) showed how in 
the case of China this collaboration does not necessarily foster the impact of these publications, which would show other factors such as currents of thinking (main stream) or the interest in social scientific topics as possible mechanisms that stimulate collaboration. However, Bordons et al. (1996) showed how in the area of biology different patterns of collaboration can exist. In this regard, it is noted that the most productive authors do not always have the same patterns of collaboration (Bordons et al., 1996). But, as is clear in the Brazilian case, the increase in the amount of products increases the likelihood of citation. Even though these variables might be important, the cluster result reported by different variables indicates the importance of different aspects of interest in the international collaboration with developing countries (He, 2009).

The cooperation dynamic seems to obey factors such as relationship stability, agreements, training and other variables of specific disciplinary interest. Part of this evidence and benefit has been found in regional publications, with collaboration alliances between researchers increasing among these publications (GarcíaMartínez et al., 2009; Navarrete-Cortés et al., 2010).

Several studies have demonstrated that productivity in psychology in Iberoamerica represents a growing number worldwide, beside the steady increase in the last years allows to predict that this growth would be higher (García-Martínez et al., 2012; Morales et al., 2012). Even further, considering the collaboration maps between the countries, there appears to be regional interest to increase this collaboration path (Figure 1). It is important to note that this cooperation brings together Latin America as a region, not through geographical proximity, but through the closeness of language. This phenomenon fosters what is called linguistic community (Figure 1).

On the other hand, when we observe the dynamic in the production of institutional collaboration, these interactions become clearer for us and we can differentiate the collaboration processes between Brazilian and Portuguese psychology on one side, and Latin American and Spanish psychology on the other (Figure 2).

In addition, citation practices of these communities affect perspectives. Thus, for example, the citation dynamic of countries such as Portugal, Brazil and Spain (Table 3) is enhanced by the number of works produced, but also by the number of authors included in a publication (Table 4).

Another characteristic of this study is that the sample of the cooperation networks is not a static network. That is, although there may be several factors that explain the cluster gathering (language, geopolitics, philosophical school), the absence of homogeneity of a single criteria suggests that these dynamics, in greater or lesser extent, affect the collaboration processes, and are changing over time. These dynamics have inspired the concept of "evolution networks" in contrast to the concept of networks of small discrete worlds, in attempts to offer insights to these projects (Jeong, Ravasz, Schubert, \& Vicsek, 2002). In this regard, within studies of cooperation and scientific impact measurement, we must consider the dynamic between researchers, institutions and the impact these have on cooperation (Deville et al., 2014).

An important limitation of the study is that, although it is possible to see the cooperation levels in different world regions, the case of Iberoamerica for example, has large production not reflected in the Scopus indicator. This is because many of the Iberoamerican publications indexed on international databases like Scopus represent only a part of the regional publications. Consequently, we recommend that future assessments of cooperation include local publications along with those indexed in the international databases. This dual-level approach would allow us to see a more representative picture of cooperation, through its inclusion of a wider range of journals.

\section{Conclusion}

Finally, we can conclude that in the field of psychology there is a tendency for international cooperation and, in the case of Iberoamerican psychology, there is variability by local dynamics. There is also variability through regional and institutional collaboration; however, there are several factors promoting and accelerating the process. Thus, factors such as the current of thought and economic status are important to consider in the process of establishing partnerships.

\section{References}

Allen, L., Brand, A., Scott, J., Altman, M., \& Hlava, M. (2014). Credit where credit is due. Nature, 508, 312-313.

Alonso, J. O., \& Sánchez, L. A. (2005). Revistas electrónicas en América Latina: Un panorama general. Revista Digital Universitaria, 6(1), 1-11.

Alzate-Medina, G. (2008). Efectos de la acreditación en el mejoramiento de la calidad de los programas de psicología de Colombia. Universitas Psychologica, 7(2), 425-439.

Arencibia Jorge, R., \& de Moya Anegón, F. (2008). La evaluación de la investigación científica: Una aproximación teórica desde la cienciometría. ACIMED, 17(4).

Barabási, A. L., Jeong, H., Néda, Z., Ravasz, E., Schubert, A., \& Vicsek, T. (2002). Evolution of the social network of scientific collaborations. Physica A, 311, 590-614.

Bordons, M., Gomez, I. I., Fernandez, M. T., Zulueta, A., \& Mendez, A. (1996). Local, domestic and international scientific collaboration in biomedical research. Scientometrics, 37(2), 279-295.

Bozeman, B., \& Corley, E. (2004). Scientists' collaboration strategies: Implications for scientific and technical human capital. Research Policy, 33(4), 599-616. doi:10.1016/j. respol.2004.01.008

Cervi, C. R., Galante, R., \& Oliveira, J. P. M. de. (2013). Comparing the reputation of researchers using a profile model and scientific metrics. In 2013 IEEE 16th International Conference on Computational Science and Engineering (pp. 353-359). doi:10.1109/CSE.2013.61 
Chinchilla-Rodríguez, Z., Vargas-Quesada, B., Hassan-Montero, Y., González-Molina, A., \& Moya-Anegón, F. (2009). New approach to the visualization of international scientific collaboration. Information Visualization, 9(4), 277-287. doi:10.1057/ivs.2009.31

Delgado, J. E. (2011). Papel del acceso abierto en el surgimiento y consolidación de las revistas arbitradas en América Latina y el Caribe. Educación Superior Y Sociedad, 16(2).

Deville, P., Wang, D., Sinatra, R., Song, C., Blondel, V. D., \& Barabási, A.-L. (2014). Career on the move: Geography, stratification, and scientific impact. Scientific Reports, 4(4770), 1-7. doi:10.1038/srep04770

Easterbrook, S. (Ed.). (1993). CSCW: cooperation or Conflict? London: Springer. doi:10.1007/978-1-4471-1981-4.

Garcia, A., Acevedo-Triana, C. A., \& López-López, W. (2014). Cooperación en las ciencias del comportamiento latinoamericanas: Una investigación documental. Terapia Psicológica, 32(2), 165-174.

García-Cepero, M. C. (2010). El estudio de productividad académica de profesores universitarios a través de análisis factorial confirmatorio: El caso de psicología en Estados Unidos de América. Universitas Psychologica, 9(1), 13-26.

García-Martínez, A. T., Guerrero-Bote, V. P., \& Moya-Anegón, F. de. (2012). World scientific production in Psychology. Universitas Psychologica, 11(3), 699-717.

García-Martínez, A. T., Guerrero-Bote, V. P., Hassan-Montero, Y., \& Moya-Anegón, F. de. (2009). La psicología en el dominio científico español a través del análisis de cocitación de revistas. Universitas Psychologica, 8(1), 13-26.

Group, S. (2014). SCImago Journal \& Country Rank. Journal Ranking in Psychology. Retrieved August 15, 2015, from http://www.scimagojr.com/

Guerrero Bote, V. P., Olmeda-Gómez, C., \& de Moya-Anegón, F. (2013). Quantifying the benefits of international scientific collaboration. Journal of the American Society for Information Science and Technology, 64(2), 392-404. doi:10.1002/asi.22754

Hassan-Montero, Y., Guerrero-Bote, V. P., \& Moya-Anegón, F. de. (2014). Graphical interface of the SCImagoJournal and Country Rank: An interactive approach to accessing bibliometric information. El Profesional de La Información, 23(3), 272-278.

He, T. (2009). International scientific collaboration of China with the G7 countries. Scientometrics, 80(3), 571-582. doi:10.1007/s11192-007-2043-y

Jeong, S., Choi, J. Y., \& Kim, J.-Y. (2013). On the drivers of international collaboration: The impact of informal communication, motivation, and research resources. Science and Public Policy, 1-12. doi:10.1093/scipol/sct079

Johnson, T. R. (2009). Cooperative research and knowledge flow in the marine commons. International Journal of the Commons.

Katz, J. S., \& Martin, B. R. (1997). What is research collaboration? Research Policy, 26(1), 1-18. doi:10.1016/ S0048-7333(96)00917-1

Kliegl, R., \& Bates, D. (2010). International collaboration in psychology is on the rise. Scientometrics, 87(1), 149-158. doi:10.1007/s11192-010-0299-0

Leydesdorff, L., \& Wagner, C. S. (2008). International collaboration in science and the formation of a core group. Journal of Informetrics, 2(4), 317-325. doi:10.1016/j. joi.2008.07.003

López, W. L., Silva, L. M., García-Cepero, M. C., Bustamante, M. C. A., \& López, E. A. (2011). Retos para la colaboración nacional e internacional en la psicología latinoamericana:
Un análisis del sistema Redalyc, 2005-2007. Estudos de Psicologia (Natal), 16(1), 17-22.

Lovón Canchumani, L. R. M., Leta, J., \& Figueiredo, A. M. de. (2013). Estudos de coautoria e cocitação: A participação brasileira no período 2000-2011. In: XIII Encontro Nacional de Pesquisa em Ciência da Informação - XIII ENANCIB, 2012, Rio de Janeiro. Anais do XIII Encontro Nacional de Pesquisa em Ciência da Informação - XIII ENANCIB. Rio de Janeiro: Fiocruz.

Morales, Y. J. G., Jaraba-Barrios, B., Guerrero-Castro, J., \& López-López, W. (2012). Entre internacionalización y consolidación de comunidades académicas locales. sobre la revista latinoamericana de psicología. Revista Colombiana de Psicologia, 21(1), 97-110.

Navarrete-Cortés, J., Fernández-López, J. A., López-Baena, A., Quevedo-Blasco, R., \& Buela-Casal, G. (2010). Global Psychology: A bibliometric analysis of web of science publications. Universitas Psychologica, 9(2), 567-582.

Porac, J. F., Wade, J. B., Fischer, H. M., Brown, J., Kanfer, A., \& Bowker, G. (2004). Human capital heterogeneity, collaborative relationships, and publication patterns in a multidisciplinary scientific alliance: A comparative case study of two scientific teams. Research Policy, 33(4), 661-678. doi:10.1016/j.respol.2004.01.007

Quevedo-Blasco, R., \& López-López, W. (2011). Situación de las revistas iberoamericanas de Psicología en el Journal Citation Reports de 2010. Universitas Psychologica, 10(3), 937-943.

Rivera-Garzón, D. M. (2008). Caracterización de la comunidad científica de Psicología que publica en la revista Universitas Psychologica (2002-2008). Universitas Psychologica, 7(3), 917-932.

Romero-Torres, M., Acosta-Moreno, L. A., \& TejadaGómez, M.-A. (2013). Ranking de revistas científicas en Latinoamérica mediante el índice h: Estudio de caso Colombia. Revista Española de Documentación Científica, 36(1), e003. doi:10.3989/redc.2013.1.876

Salazar-Acosta, M., Lucio-Arias, D., López-López, W., \& Aguado-López, E. (2013). Informe sobre la producción cientifica de Colombia en revistas iberoamericanas de acceso abierto en redalyc.org 2005-2011 (pp. 1-160). Ciudad de México: Universidad Autónoma del Estado de México.

Shen, H.-W., \& Barabasi, A.-L. (2014). Collective credit allocation in science. Proceedings of the National Academy of Sciences, 111(34), 12325-12330. doi:10.1073/pnas.1401992111

Vera-Villarroel, P., López-López, W., Lillo, S., \& Silva, L. M. (2011). La producción científica en psicología latinoamericana : Un análisis de la investigación por países. Revista Latinoamericana de Psicologia, 43(1), 95-104.

Zych, I., \& Buela-Casal, G. (2010). Internacionalidad de las revistas de psicología multidisciplinar editadas en Iberoamérica e incluidas en la web of science. Universitas Psychologica, 9(1), 27-34. 